\title{
Exploring the Relationship between Corporate Social Responsibility and Sales Growth of Small and Medium Enterprises: A Combined Case Study in the Light of a Literature Review
}

\author{
Jintao Lu ${ }^{1,2, *}$, Dan Rong ${ }^{1}$, Chong Zhang ${ }^{1}$, Chunyan Wang ${ }^{1}$, \\ Parvaneh Saeidi $^{3}$, Justas Streimikis ${ }^{4}$
}

${ }^{1}$ Department of Business Administration, School of Economics and Management, Taiyuan University of Science and Technology, Taiyuan 030024, P. R. China, email: lujintao@tyust.edu.cn (J. L.); S20190744@stu.tyust.edu.cn (D. R.); zhangchong@tyust.edu.cn (C. Z); S20190745@stu.tyust.edu.cn (C. W.)

${ }^{2}$ Research Center for Corporate Social Responsibility, Taiyuan University of Science and Technology, Taiyuan 030024, P. R. China

${ }^{3}$ Facultad de Negacios, Universidad del Pacifico, Ecuador, e-mail:

Parvaneh.saeidi@upacifico.edu.ec

${ }^{4}$ Lithuanian Institute of Agrarian Economics, A. Vivulskio g. 4A-13, 03220

Vilnius, Lithuania; The University of Economics and Human Science in Warsaw, Okopowa 59, 01-043 Warsaw, Poland, justas.streimikis@laei.lt

\footnotetext{
Abstract: The purpose of this study is to analyze the influence of Corporate Social Responsibility (CSR) on a firms' sales growth and to assess the mediating role of competitive advantage and the moderating role of the employee's individual belief of social responsibility (SR) on the relationship between CSR and sales growth of small and medium enterprises. A survey of 107 small and medium enterprises (SMEs) in the consumption and manufacturing industry of a developing country was performed. Structural equation modeling based on AMOS path was employed to test the hypotheses linked to the relationship between CSR and sales growth of SMEs. Results indicate that the link between CSR and sales growth is mediated through competitive advantage and that the positive impact of CSR on sales growth is moderated by the employee's individual belief of social responsibility.
}

Keywords: corporate social responsibility; competitive advantage; employee's individual belief of social responsibility; small and medium enterprises 


\section{Introduction}

Corporate Social Responsibility (CSR) has been acknowledged by companies, institutions, organizations and society, as the main trend of sustainable business development providing also for competitive advantage of the companies. It has therefore sparked an interest within academic communities, both locally and globally, to study corporate social responsibility initiatives from diverse angles covering strategic goals $[13,51,55,76]$ has been referred as a term in which the multi-faceted associations between companies and societies are represented [38, $39,80,68]$.

It is obvious that there are many relations between the economic, social and environmental issues of all business activities though traditionally companies were mainly concentrated on economic aspects in their actions. The scholars [29, 43, $51,73,76]$ in their studies showed that for generation of revenue or profits companies need to address consumers' behavior. Therefore, firms should not only be too obsessed with the profitability without giving any consideration to societies' needs and expectations. For instance, in the present ground reality of businesses, customers appear to have a certain level of awareness and concerns about environment, leading to increased demand in environmentally friendly products and services. Thinking along these lines, it can therefore be presumed that the asserted relationship between CSR and firm execution appear to be more muddled than what the related former analyses have reported. Therefore, there is a strong need to demystify the complexities of the link between environmental, economic, and social aspects by means of rigorous empirical investigations.

In this regard, this study attempts bridge some gaps identified in the preceding investigations and to extend extending some views developed by these studies by linking economic, social and environmental issue of CSR with profitability of companies. For this reason, a competitive advantage which is closely linked to firms' ability to increase satisfaction and loyalty of customers is being measured as the outcome of being environmentally friendly. In relation to this, a relevant question to address this aspect was asked in this study: 'Does being responsible toward the environment lead to firms' sales growth through the competitive advantage as a mediator?'.

It is worth noting, that most scholars investigated the benefits of CSR, by putting more attention on the financial issues linked to CSR and were not dealing the impacts on employees. However, considering the presently fast increment of CSR practices, an inquiry into the CSR, representatives' states of mind and firms' execution have jointly become essential. Scholars have therefore attempted to investigate how employees' perceived CSR may affect different aspects of firms' outcomes. Some studies analyzed the impacts of perceived CSR on employees' commitments $[63,69]$. Other scholars examined the effect of CSR on employees' performance $[25,26,30,70]$. Several studies analyzed the influence of CSR on 
perceptions and disposition of potential employees and current workers of companies [2, 20, 33, 48]. In these studies, CSR was being considered as an independent factor and employees' outcomes were being analyzed as dependent factors. These studies found that CSR initiatives have positive impact on relationships between the organizations and its employees however the quality of these relationships and the main drivers of it are not fully addressed in these studies.

Therefore, the current study attempts to fill this gap identified in the literature by means of investigating the level and effect of employees' individual perceptions of social responsibilities as a moderator on CSR-sale growth relationship and to address the role of competitive advantage as mediator in relationship between CSR and sales growth of the company.

Considering the essential advances that have been made, thus far and moving to the center of CSR, one of the aspects which have received considerably less consideration within this wide research plan relates to a particular focus on small and medium enterprises (SMEs) in CSR among the developing countries. For these countries CSR issues are new but have very important impact on their sustainable development taking into account the important challenges addressed by Sustainable Development Goals (SDG). Scholars stressed that the collective grandness of small businesses has often have been underestimated in CSR studies $[39,59]$. SMEs have therefore been fundamentally contributing to the creation of occupations and lightening poverty among developing nations. Estimated to represent about $90 \%$ of businesses internationally and half to $60 \%$ of occupations, SMEs have been depicted as the imperative spines of sound monetary developments and essentialness, as they help improve the livelihood, in support of the young entrepreneurial ability and significantly contribute to the systemic gainful limits that may in turn serve to encourage competitions and innovations of developing nations [40]. Additionally, SMEs are also found to be unequivocally established in their respective communities, and they are mostly nearer to their workers and group supporters [23, 39, 41, 61]. In this regard, a sample of SMEs drawn from a developing country in which, local firms are expected to actively assist their surrounding communities could be useful in relating CSR results to an overall setting [76]. Therefore, Iran has been selected for this case study as developing nation having important SMEs sector starting to implement CSR initiatives.

The rest of the paper is structured in the following way: Section 2 presents literature review and hypotheses development; Section 3 introduces methods, sampling and data; Section 4 discusses the results of study and the last, Section 5, concludes. 


\section{Literature Review and Hypotheses Development}

The literature review performed in this section of paper aims to develop hypotheses for empirical study in Iranian SMEs. The studies dealing with CSR impacts on sales growth of the firm are discussed thereafter. The CSR is broadly defined as firm's commitment to avoid negative consequences and to maximise long-term benefit for the society [16, 20, 49, 56, 81, 82]. Authors [44, 80] stressed ethical responsibility of companies in development of CSR concept. Carroll's [14, 15] concept of CSR is one of the best known and accepted. It includes the main notion that the goal of the company in modern society is not only increase in profits but also its responsibility towards society. Many scholars [10, 20, 29, 76] used the same position and classification of social responsibilities of companies introduced by Caroll [14, 15]: cultural, economic, social, ethical, legal, environmental etc. The Carroll's dimension of CSR was revised by scholars [50, $51,47,48]$ in order to address the firm's acknowledgment of CSR.

As has been discussed in the foregoing, the main aim of the company is to produce more prosperity and profits for it's the shareholders. The revenues of companies mainly originate from their sales of products, and this is closely linked with consumer's satisfaction and loyalty. Therefore, the customer satisfaction was defined as the main driver of firm's long-term growth and profitability in several studies [29, 52, 67].

Conversely, some scholars $[43,80]$ also disputed that satisfaction of consumers itself is not directly linked with financial performance of company but it has influence on the reputation, image and brad of companies. Many studies analysed the impact of corporate reputation and consumer loyalty on competitive advantage of companies and confirmed the positive effects [7, 10, 18, 20, 33, 29]. Researchers $[54,46]$ pointed out that this can help to improve significantly the level of satisfaction among customers. So, shareholders may assess the level of success of the company growth not on financial performance indicators but also based on implementation of social responsibility programs as was confirmed by Barnett and Salomon [6]. Few other scholars [36, 62] highlighted that the competitive advantage is the main result of customer satisfaction due to implementation of CSR. To sum up, number of studies $[46,76,82]$ indicated that firms currently understand that CSR initiative is attractive for the buyers and society and provides a favourable image influencing positively consumers' attitudes toward the firms and increase in firms competitive advantage.

It is clear that increase in competitive advantage provides more financial benefits for companies and ensures their long-term growth. Many researchers [54, 62, 68, $75,78]$ showed in their studies that firms are implementing different, new and possible marketing strategies to attract more and more satisfied customers every day with the intention increasing the competitive advantage, and that a company's success may depend mainly on that factor. These studies have concentrated on the 
expectation of new customers about products and services of companies and proved that these are no longer linked with quality and price alone but also with environmental awareness level of the society members and their increasing demands for environmentally friendly products. The studies dealing with competitive advantage [7, 9, 18, 52, 66, 67] highlighted the following factors important for assessing comparative advantage of firms: strong brand, corporate image and reputation, innovations, market position and leadership and other intangible assets of growing importance. The comprehensive review of literature to date has revealed that most of the scholars examined the relationship between CSR and financial performance of companies by dealing with its main antecedents: customer satisfaction and corporate image, however there are no studies dealing with the role of competitive advantage in the relationship between CSR and sales growth. Therefore, the first hypothesis (H1) was developed to address this gap:

H1: The competitive advantage of company is the mediator of the effect of CSR on its sales growth.

The scholars $[64,65,84]$ agree that employees are the most important drivers of the company's goal achievements. However, most studies focused on external stakeholders such as customer's environmental awareness. Of course, all stakeholders but especially internal such as employees are tightly involved in supporting and implementing main goals of the firm's strategy as highlighted by several studies [19, 24, 42]. Porter and Kramer [64] stressed the importance of employees in implementing CSR initiatives. It is possible to guess that awareness of the social responsibilities and acceptance by employees are necessary for delivering social and environmental objectives of companies as pointed by Bauman and Skitka [11]. Similarly, Renouard and Ezvan [71] and Greening and Turban [31] revealed that firms' positive attitudes and imagination are interrelated with job satisfaction and less willingness on the part of the employees to consider changing their current workplace. The positive CSR perceptions may directly influence the rate of job satisfaction of managers [21]. Carrol [14] explained that perceptions on CSR, in relation to the concentration of firms on improving their quality of products and services. This may make management teams and employees to get along better and therefore lead to a better relationship on one hand, and create a better working environment in which support for current staff members and an increase in employee retention rate which may eventually lead to higher job performance level on the other [67].

Some studies [45, 63] found that CSR affects CSR perceptions and, consequently, employees' performance, loyalty and organizational commitments. The work environment has also positive influence on employees' performance therefore employees prefer in socially responsible companies based on several works [2, 33]. 
Referring to the discussion in the foregoing along with a comprehensive review of literature, there were studies which have focused mainly on examining the employees' perceptions on companies' involvement in social and environmental issues and their effects on their work performance on one hand and investigating the influence of CSR on attracting more qualified employees on the other. Unlike the previous related studies, the present study reasons that the relationship between CSR and firms' sales growth are moderated positively by means of the relatively higher level of employees' individual beliefs of social responsibilities. Accordingly, the researcher hypothesizes the following:

H2: Higher level of employees' individual beliefs of social responsibility makes the effect of CSR on sales growth stronger.

Unlike the existing instruments reported in the literature which only focused on the employees' perceptions on companies' involvement in social and environmental issues [5, 45, 72, 79 ], a proper and relevant scale was therefore adapted from work by Jamali, Zanhour and Keshishian [37] for the present study. Respondents of the related previous studies were managers, whereas in this study, employees were recruited as respondents to provide their self-reported responses to the questions in the questionnaire. Therefore, questions were changed to employees' personal attitudes and perspectives. Accordingly, fourteen items were used to measure to what extent employees believe the true nature of SR. Opinions were indicated using a five-point scale indicating by "1" (strongly disagree) and by " 5 "' (strongly agree). Figure 1 shows the study framework.

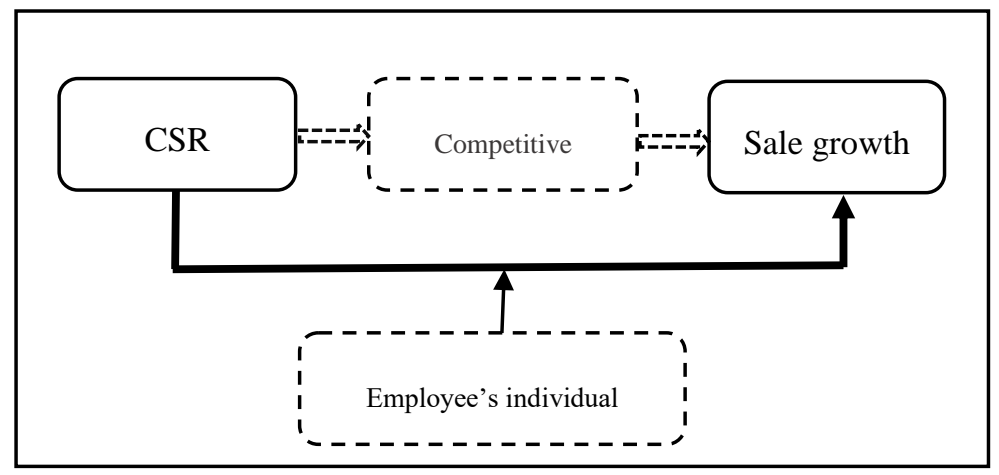

Figure 1

Conceptual Framework of the study 


\section{Research Method and Data}

Academic research by and large, has paid most of their attention to large companies while small medium enterprises (SMEs) are left with more complicated challenges facing which, gaining a competitive advantage for relatively longer periods of time is therefore more complex. As described by Jenkins [38], when these small organizations are summed, their impact on societies and environment can be potentially great. Therefore, general assumptions about CSR should be adapted to SME contexts [10, 38, 57, 59, 76]. Notwithstanding the significance, related studies reported in the literature helped discover that there is still a gap identified in CSR for SMEs, and there is still a long way ahead to manage CSR-SMEs by means of a constructed model particularly in the contexts of developing countries [4, 27, 39, 74, 84]. Consequently, upon a comprehensive review of literature along with validating new hypotheses, this study therefore, has formulated the objective of carrying out a case study of CSR-SMEs in the context of Iran as a developing country in which, CSR has not been adequately addressed both in practical and theoretical terms in other conducted studies [18, 19, 55, 78].

\subsection{Sampling}

Survey was considered one of the most suitable ways to gather information for this study owing to the fact that there was no comprehensive database available for SMEs in the context of Iran. About 843 SMEs within consumer and manufacturing product sectors from four big cities in Iran were shortlisted for this study. It was assumed that at least 2 managers and 4 employees of all listed firms randomly answer their respective questionnaires. Three related parts: CSR, competitive advantage and sales growth were answered by top managers, because they were more familiar with their respective companies' affairs and had firsthand knowledge about the improvement processes, while employees' individual beliefs of social responsibilities were answered by employees.

Upon collecting the questionnaires, firms in which only managers responded or only employees responded were eliminated from the data of the study and only firms with both managers and employees have responded were considered for analysis purposes. The overall clear response rate was $28 \%$ (i.e., 107 out of 843 firms). Even though the return rate was considered lower, it was however not unusual, because the response rate among top managers within CSR contexts is reportedly lower in general. For example, [29, 55, 48, 76] reported that their response rate was between $6 \%$ to $17 \%$. Another scholar i.e., [84] found that the response rate is an element of how imperative the idea of CSR is seen in every nation, so that higher response rate in developed nations may indicate that CSR is an issue in relation to their business plans, while lower response rates in less developed nations may suggest that it is not a significant issue among 
entrepreneurs. Along these lines, in light of the all related evidences, a return rate of $28 \%$ ought to be adequate for a developing nation like Iran, in which CSR has not been essentially intended.

\subsection{Measurement Model}

Structural equation modelling was found to be the proper statistical analysis technique for this study and AMOS on the other hand as the appropriate analysis software to run tests. This is because; Rowley and Berman [75] and [3, 29] believed that SEM is deemed more fitting than the other conventional regression analysis in relation to CSR research. Therefore, it can be explained that the SEM is capable of simultaneously testing the causal relationships between independent variables and multiple dependent variables as opposed to the first-generation techniques which may not be able to do so. Furthermore, they also claimed that SEM is considered better because it can significantly reduce bias by taking measurement errors into account. Moreover, [37] demonstrated observationally that SEM approaches which in many cases are considered reliable, can be more capable of identifying an intercession results than the regression approach.

Confirmatory Factor Analysis CFA was employed to examine the fitness of the model in which, all variables were assigned to load on one single factor. Only items with a factor loading of greater than 0.6 were selected as belonging to a specific factor in this study. In addition to factor loading, convergent validity was likewise measured by means of Average Variance Extracted (AVE). It is considered adequate when the AVE value of each construct exceeding 0.5 [35]. Moreover, according to [34] that the value of a Cronbach's alpha being greater than 0.7 may indicate relatively a higher level of internal reliability. It is worth noting that all Cronbach's alpha values involved in this study were at acceptable levels. Table 1 delineates the final results of the convergent validity and reliability tests after deleting several items which were considered unnecessary.

Table 1

Convergent validity and reliability

\begin{tabular}{|l|l|l|l|l|l|}
\hline Variable & Mean & SD & $\begin{array}{l}\text { Internal } \\
\text { consistency }\end{array}$ & $\begin{array}{l}\text { Cronbach's } \\
\text { alpha }\end{array}$ & AVE \\
\hline CSR & & & & & \\
\hline Ethical & 3.28 & 0.55 & 0.89 & 0.79 & 0.61 \\
\hline Economic & 3.97 & 0.71 & 0.87 & 0.83 & 0.73 \\
\hline Discretionary & 4.01 & 0.52 & 0.77 & 0.81 & 0.55 \\
\hline Legal & 3.67 & 0.61 & 0.93 & 0.92 & 0.59 \\
\hline Competitive advantage & 3.92 & 0.55 & 0.80 & 0.86 & 0.67 \\
\hline Employees' individual beliefs of SR & 3.52 & 0.73 & 0.83 & 0.77 & 0.71 \\
\hline Sale growth & 4.06 & 0.59 & 0.74 & 0.94 & 0.82 \\
\hline
\end{tabular}


In Table 2, the AVE values for all of the study's constructs were well over the limit, and the square base of the AVE esteem in the slanting for every construct was bigger than the relationship coefficients in the comparing lines and sections. Hence, a higher discriminant validity of the collected data existed as well [28]. All discriminant, convergent validities and reliability were found to be at significant levels in this study.

Table 2

Correlations and square root of AVE value

\begin{tabular}{|l|l|l|l|l|l|l|l|}
\hline Variable & $\mathbf{1}$ & $\mathbf{2}$ & $\mathbf{3}$ & $\mathbf{4}$ & $\mathbf{5}$ & $\mathbf{6}$ & $\mathbf{7}$ \\
\hline 1) Ethical dimension of CSR & $\mathbf{0 . 7 8}$ & & & & & & \\
\hline 2) Economic dimension of CSR & 0.21 & $\mathbf{0 . 8 5}$ & & & & & \\
\hline 3) Discretionary dimension of CSR & 0.08 & 0.03 & $\mathbf{0 . 7 4}$ & & & & \\
\hline 4) Legal dimension of CSR & 0.11 & 0.10 & 0.09 & $\mathbf{0 . 7 6}$ & & & \\
\hline 5) Competitive advantage & 0.36 & 0.43 & 0.25 & 0.31 & $\mathbf{0 . 8 1}$ & & \\
\hline 6) Employee beliefs of SR & 0.12 & 0.11 & 0.13 & 0.29 & 0.20 & $\mathbf{0 . 8 4}$ & \\
\hline 7) Sale growth & 0.41 & 0.34 & 0.46 & 0.58 & 0.38 & 0.39 & $\mathbf{0 . 9 0}$ \\
\hline
\end{tabular}

The hypotheses in this study were tested by SEM. Structural Equation Modelling is the main technique to examine and the relationships among research constructs, to test hypotheses of studies in order to identify latent variables in the conceptual model designed by researchers as well as to define the direction and significance of these relationships $[3,12]$. The moderating effects were tested in this study by conducting a multiple sample analysis in the SEM competing model [42]. In addition to moderating test i.e., the mediating effects were tested according to procedures established by [8]. The findings of the study are discussed in the following sections.

\section{Discussion of Results}

According to the four steps approach presented by [8], the collected results from the principal model (i.e., CSR-sale growth relationship) may demonstrate that there is a positive and significant relationship between CSR as the second order and also all measurements of CSR as the main order variables and sale growth. Before running the tests, the levels of root mean square (RMR), comparative fit index (CFI) and goodness of fit index (GFI), which should be less than 0.05 for RMR, and more than 0.9 for CFI and GFI were then tested. The basic model showed that GFI $=0.951, \mathrm{CFI}=0.921, \mathrm{RMR}=0.035$, Chi Square $=55.949$, which indicated that the model was considered suitable for the general model fit evaluation of path direct connections. Table 3 and Table 4 provide the summary of the results of the Path direction relationships of the study. 
Table 3

Path direct relationship

\begin{tabular}{|c|c|c|c|c|c|}
\hline \multicolumn{3}{|l|}{ Path } & \multirow{2}{*}{$\frac{\text { Path Co }}{\text { 0.58 }}$} & \multirow{2}{*}{\begin{tabular}{|l}
$\mathrm{P}$ \\
$* * *$
\end{tabular}} & \multirow{2}{*}{$\begin{array}{l}\text { Hypothesis } \\
\text { Supported }\end{array}$} \\
\hline H1: CSR & es & Sale growth & & & \\
\hline Ethical dimension & es & Sale growth & 0.38 & $* * *$ & Supported \\
\hline Economic dimension & $e s$ & Sale growth & 0.49 & $* * *$ & Supported \\
\hline Discretionary dimension & ess & Sale growth & 0.41 & $* * *$ & Supported \\
\hline Legal dimension & es & Sale growth & 0.18 & $* * *$ & Supported \\
\hline$* * * p<0.001$ & & & & & \\
\hline
\end{tabular}

The initial condition of building up the mediation was created with all significant effects of CSR components on sale growth. After including the mediator variable and running the second model to test $\mathrm{H} 1$, it was revealed that the CSR and sales growth relationships were fully mediated relationships by means of the influence of CSR to sales growth via gaining higher competitive advantage (see Table 4).

Table 4

Main effects of variables in mediating model (H1)

\begin{tabular}{|l|l|l|c|c|c|l|}
\hline & & & Estimate & S.E. & C.R. & P \\
\hline CSR & Sale growth & 0.014 & 0.065 & 0.215 & 0.52 \\
\hline CSR & $\longleftarrow$ & Ethical dimension of CSR & 0.502 & 0.146 & 3.438 & $* * *$ \\
\hline CSR & Economic dimension of CSR & 0.382 & 0.107 & 3.570 & $* * *$ \\
\hline CSR & $\begin{array}{l}\text { Discretionary dimension of } \\
\text { CSR }\end{array}$ & 0.229 & 0.051 & 4.490 & $* *$ \\
\hline CSR & Legal dimension of CSR & 0.432 & 0.102 & 4.235 & $* *$ \\
\hline CSR & Competitive advantage & 0.686 & 0.176 & 3.897 & $* * *$ \\
\hline $\begin{array}{l}\text { Competitive } \\
\text { advantage }\end{array}$ & Sale growth & 0.704 & 0.132 & 5.333 & $* * *$ \\
\hline
\end{tabular}

$* * p<0.01 * * * p<0.001$

By means of adhering to [8] steps to create a mediated association, it was discovered that there was a meaningful connection between CSR as the independent variable and competitive advantage as the hypothesized mediating variables (i.e., meeting second step). Competitive advantage is a predictor of the dependent variable (i.e., meeting third step). The last circumstance for establishing mediation also happened, because the relationship between CSR and sales growth in the revised model was no longer considered significant than the direct effect model. Accordingly, the gained outputs in Table 3 and Table 4 support the fullymediated relationship and thus showed that all CSR dimensions and sales growth were connected through higher competitive advantage that may come after CSR. 
In order to evaluate the moderating effects of employees' perception on CSR, the study compared the first model (original) against the competing model. It is worth noting that in addition to testing the moderating effects on the relationship between second order variable (CSR) and sales growth, the moderating effects of the moderator on all first order variables' relationships with sales growth were also tested.

The original model with second order variable showed that GFI $=0.951, \mathrm{CFI}=$ 0.921 , Chi-square $=55.949, \mathrm{p}<0.001$. In the competing model of the second order variable, after introducing the moderating role of employee's individual perception of SR on CSR-sales growth relationship, the results showed that GFI = $0.913, \mathrm{CFI}=0.912, \mathrm{RMR}=0.028$, Chi-square $=77.277, \mathrm{p}<0.001$. Significant increase in Chi-square confirms the moderating effect of employee perception of CSR on the influence of CSR on sales growth (see Table 5).

Table 5

Main effects of variables in moderating model (second order variable on sale growth)

\begin{tabular}{|c|c|c|c|c|c|c|c|}
\hline & & & Chi-squ & & & & \\
\hline $\begin{array}{l}\text { Path } \\
\text { relations }\end{array}$ & & construct & $\begin{array}{l}\text { Original } \\
\text { model }\end{array}$ & $\begin{array}{l}\text { Competing } \\
\text { model }\end{array}$ & $\begin{array}{l}\text { value } \\
>1.96\end{array}$ & Results & f2 \\
\hline $\begin{array}{l}\text { CSR } \times E B \\
\text { of SR }\end{array}$ & 20 & Sale growth & 55.949 & 77.277 & 2.549 & $* *$ & $\begin{array}{l}0.279 \\
\text { (medium) }\end{array}$ \\
\hline
\end{tabular}

$* * \mathrm{p}<0.01$

EB of SR: Employee's individual beliefs of Social Responsibility

Furthermore, in the second model, with all first order variables, the original model showed that GFI $=0.911, \mathrm{CFI}=0.903, \mathrm{RMR}=0.042$, Chi-square $=61.658$, $\mathrm{p}<0.001$. In the competing models, of all first order variables, which were tested separately, the moderating effect of employees' individual perceptions of CSR on the influences of all CSR components on sales growth was confirmed. The results showed that the moderator may therefore have a positive and significant effect on the relationship between all first order variables and sales growth (see Table 6). Notwithstanding, these results are not $100 \%$ clear without knowing the size of the moderator effects on such relationships. Therefore, in addition to examining the changes in Chi-square, the effect sizes of moderator were also examined through Cohen's f2.

Cohen 's $f^{2}=\frac{\text { Rsq(competing mod el })- \text { Rsq(original mod el })}{1-\text { Rsq(competing mod el })}$

Based on the Cohen's formula, if $f 2$ is situated between 0.02 and 0.15 , the effect of size can be smaller; if $f 2$ is situated between 0.15 and 0.35 , the effect of size can be medium, and if $f 2$ is greater than 0.35 , the effect of size can be huge [36]. 
Table 6

Main effects of variables in moderating model (All first order variables on sale growth)

\begin{tabular}{|c|c|c|c|c|c|c|}
\hline & & Chi-squ: & & & & Iff \\
\hline $\begin{array}{l}\text { Path } \\
\text { relationships }\end{array}$ & construct & $\begin{array}{l}\text { Original } \\
\text { model }\end{array}$ & $\begin{array}{l}\text { Competing } \\
\text { model }\end{array}$ & $\begin{array}{l}\text { value } \\
>1.96\end{array}$ & results & \\
\hline $\begin{array}{l}\mathrm{H} 2_{\mathrm{a}}: \quad \text { Ethical } \\
\times \mathrm{EB} \text { of } \mathrm{SR}\end{array}$ & es $\begin{array}{l}\text { Sale } \\
\text { growth }\end{array}$ & 61.658 & 84.242 & 8.921 & $* * *$ & $\begin{array}{l}0.372 \\
\text { (big) }\end{array}$ \\
\hline $\begin{array}{l}\mathrm{H} 2 \mathrm{~b} \text { : Economic } \\
\times \mathrm{EB} \text { of } \mathrm{SR}\end{array}$ & 2o $\begin{array}{l}\text { Sale } \\
\text { growth }\end{array}$ & 61.658 & 72.867 & 5.701 & $* * *$ & $\begin{array}{l}0.184 \\
\text { (medium) }\end{array}$ \\
\hline $\begin{array}{l}\mathrm{H} 2 \mathrm{c}: \\
\text { Discretionary } \\
\times \text { EB of SR }\end{array}$ & \begin{tabular}{|l|l} 
Sale \\
growth
\end{tabular} & 61.658 & 64.908 & 3.074 & $* *$ & $\begin{array}{l}0.053 \\
(\text { small })\end{array}$ \\
\hline $\begin{array}{l}\mathrm{H} 2 \mathrm{~d}: \quad \text { Legal } \\
\times \mathrm{EB} \text { of SR }\end{array}$ & $\begin{array}{l}\text { Ses } \\
\begin{array}{l}\text { Sale } \\
\text { growth }\end{array}\end{array}$ & 61.658 & 69.007 & 3.611 & $* *$ & $\begin{array}{l}0.121 \\
\text { (small) }\end{array}$ \\
\hline
\end{tabular}

$* * \mathrm{p}<0.01 * * * \mathrm{p}<0.001$

EB of SR: Employee's individual beliefs of Social Responsibility

During comparison of the results shown in Table 5 and Table 6, all Chi-squares of the competing models were found to be bigger than the original models. Moreover, all t-values were observed to be greater than 1.96. These results were used to conclude that the moderating effect of higher level of employees' individual beliefs of CSR was all significant. Thus, H2 and its all sub-hypotheses were supported.

The effect of size showed that higher level of employees' individual beliefs of SR as moderator may have the biggest positive effect on ethical dimension of CSRsales growth relationship, followed by on economic dimension, then legal dimension, and at last, the smallest positive effect can be observed on the discretionary dimensions of CSR-sales growth relationship. Therefore, the findings of this study have confirmed and supported all previous studies indicating the positive influence of CSR on various indicators of financial performance of companies [1, 29, 46, 51, 76, 83]. Therefore, considering the reproach of some scholars $[1,29 ; 51,73]$ against some studies in which the direct relationship between CSR and firm financial performance being examined along with CSR and sales growth respectively, the researcher of the present study similarly assumed that the engagement in CSR may affect the sales growth by improving the competitive advantage. Finally, the findings of this study have supported the hypothesis that the association between CSR and firms' performance is a fully mediated relationship by the competitive advantage among SMEs in the context of Iran. These findings have also supported the most recent findings reported by [76] which was carried out among large companies in the context of Iran and have discovered mediated relationship between CSR and the sampled firms' financial performance by means of the competitive advantage. In addition to considering 
the effective roles of customers towards CSR and achieving a relatively higher level of sales growth, the researcher also examined the effects of employees' individual beliefs of social responsibilities on CSR-sale growth link.

The findings of the present study are also supported by Resource-Based Theory (RBT). The main dependent construct of RBT is sustainably competitive advantage and the main independent constructs are assets, capabilities, and resources as in studies [17, 22, 24]. A company's failure or success rate is substantially determined by means of the firms' resources and the competitive advantage under the RBT theory [60]. In this regard, [53] have considered CSR as a main resource which may lead to more sales and higher financial performance of firms. Therefore, RBT is the most suitable theory to support the findings of the present study. Although CSR has not been adequately addressed in the context of Iran both practically and academically $[18,19,55,78]$, these results are, however, consistent with those of other studies which were carried out mainly in developed countries and they have found positive effects of CSR on firms' financial performance in their respective contexts.

\section{Conclusions}

This case study was performed in the SME sector, of a developing country. It examined the moderating effects of the employees' individual beliefs about SR, in the relationship between implementation of CSR initiatives and sales growth. The study also assessed the moderating role of competitive advantage in the relationship between CSR and sales growth.

The results of this study have revealed that SMEs with more socially responsible employees found it is easier to implement their strategies and CSR initiatives and consequently to achieve relatively higher sales and better results, in financial performance and profits.

The main findings suggest that for SMEs, it is advisable to implement CSR initiatives, as currently, customers are taking into account CSR practices, in their decisions to purchase products and services and most employees desire to work in socially responsible firms.

The findings of the study are consistent with results of other studies which were performed, mainly in developed countries, and they have also obtained the positive effects of CSR on firms' financial performance in their respective contexts.

The study has significantly contributed to the CSR domain in developing countries. From the point of view of knowledge, it has contributed by means of overcoming some of the complexities surrounding the asserted connection between CSR and the performance of firms. This work has also extended the literature on CSR, for which, a framework which may potentially assist to clarify, how CSR might be related to sales growth. 
In terms of the practical contributions, the study may increase the level of knowledge among firms' managers, concerning the significance of CSR, as an approach that may produce intangible benefits, such as, more experts and loyal personnel, better levels of customer satisfaction and an enhanced competitive advantage.

\section{Funding}

This work was supported by the Program for the Innovative Talents of Higher Education Institutions of Shanxi (PTIT) under Grant (20191043); Key R\&D Program of Shanxi Province, China (Social Development) under Grant (201903D321004).

\section{References}

[1] Alafi, K., \& Alsufy, F.: Corporate social responsibility associated with customer satisfaction and financial performance a case study with Housing banks in Jordan, International Journal of Humanities and Social Science, 2 (2012) No. 15, pp. 102-115

[2] Albinger, H. S., \& Freeman, S. J.: Corporate social performance and attractiveness as an employer to different job seeking populations, Journal of Business Ethics, 28 (2000) pp. 243-253

[3] Anderson, J. C., \& Gerbing, D. W.: Structural equation modeling in practice: a review and recommended two-step approach, Psychological Bulletin, 103 (1988) No. 3, pp. 411-423

[4] Baden, D., Harwood, I. A., \& Woodward, D. G.: The effects of procurement policies on 'downstream' corporate social responsibility activity: content-analytic insights into the views and actions of SME ownermanagers, International Small Business Journal, 29 (2011) No. 3, pp. 259277

[5] Bagire, V. A., Tusiime, I., Nalweyiso, G., \& Kakooza, J. B.: Contextual environment and stakeholder perception of corporate social responsibility practices in Uganda, Corporate Social Responsibility and Environmental Management, 18 (2011) No. 2, pp. 102-109. doi:10.1002/csr.252

[6] Barnett, M. I., \& Salomon, R. M.: Beyond dichotomy: the curvilinear relationship between social responsibility and financial performance, Strategic Management Journal, 27 (2006) No. 11, pp. 1101-1122

[7] Barney, J.: Firm resources and sustainable competitive advantage, Journal of Management, 17 (1991) No. 1, pp. 99-120

[8] Baron, R. M., \& Kenny, D. A.: The moderator-mediator variable distinction in social psychological research: conceptual, strategic and statistical considerations, Journal of Personality and Social Psychology, 51 (1986) No. 6, pp. 1173-1182 
[9] Bataineh, M. T., \& Zoabi, M. A.: The effect of intellectual capital on organizational competitive advantage, Jordanian commercial banks (Irbid district). An empirical study, International Bulletin of Business Administration 10 (2011) pp. 15-24

[10] Battaglia, M., Testa, F., Bianchi, L., Iraldo, F., \& Frey, M.: Corporate Social Responsibility and competitiveness within SMEs of the fashion industry: Evidence from Italy and France, Sustainability, 6 (2014) No. 2, pp. 872-893

[11] Bauman, C. W., \& Skitka, L. J.: Corporate social responsibility as a source of employee satisfaction, Research in Organizational Behavior, 32 (2012) pp. 63-86, doi:http://dx.doi.org/10.1016/j.riob.2012.11.002

[12] Baumgartner, H., \& Homburg, C.: Applications of structural equation modeling in marketing and consumer research: a review, International Journal of Research in Marketing, 13 (1996) No. 2, pp. 139-161

[13] Carmeli, A., Gilat, G., \& Waldman, D. A.: The role of perceived organizational performance in organizational identification, adjustment and job performance, Journal of Management Studies, 44 (2007) No. 6, pp. 972-992

[14] Carroll, A. B.: A Three-Dimensional conceptual model of corporate performance, The Academy of Management Review, 4 (1979) No. 4, pp. 497-550

[15] Carroll, A. B.: Managing ethically with global stakeholders: A present and future challenge, Academy of Management Executive, 18 (2004) No. 2, pp. $114-120$

[16] Cavusgil, S. T., \& Knight, G.: Born global firms: a new international enterprise, New York: Business Expert Press, 2009

[17] Chang, C. H.: The influence of corporate environmental ethics on competitive advantage: the mediation role of green innovation, Journal of Business Ethics, 104 (2011) No. 3, pp. 361-370

[18] Chapardar, H., \& Khanlari, R.: Iranian corporations and Corporate Social Responsibility: an overview to adoption of CSR themes. 2011, SAGE Open, available in: http://sgo.sagepub.com/content/early/2011/11/18/ 2158244011430988

[19] Choi, Y., \& Yu, Y.: The influence of perceived corporate sustainability practices on employees and organizational performance, Sustainability, 6 (2014) No. 1, pp. 348-364

[20] Crifo, P., \& Forget, V. D.: The economics of Corporate Social Responsibility: a firm-level perspective survey, Journal of Economic Surveys, 29 (2015) No. 1, pp. 112-130 
[21] Dana, L. P., Welpe, I. M., Han, M., \& Ratten, V.: Handbook of research on european business and entrepreneurship: towards a theory of internationalization, Cheltenham, UK: Edward Elgar Publishing, 2008, pp. 800

[22] Demuijnck, G., \& Ngnodjom, H.: Responsibility and informal CSR in formal Cameroonian SMEs, Journal of Business Ethics, 112 (2013) No. 4, pp. 653-665, doi:10.1007/s10551-012-1564-3

[23] Etemed, H.: International entrepreneurship in small and medium size enterprises: orientation, Environment and Strategy, Cheltenham, UK: Edward Elgar Publishing, 2004, p. 277

[24] Farooq, M., Farooq, O., \& Jasimuddin, S. M.: 'Employees response to corporate social responsibility: exploring the role of employees' collectivist orientation', European Management Journal, 32 (2014) No. 6, pp. 916-927, doi:http://dx.doi.org/10.1016/j.emj.2014.03.002

[25] Farooq, O., Payaud, M., Merunka, D., \& Valette-Florence, P.: The Impact of Corporate Social Responsibility on organizational commitment: exploring multiple mediation mechanisms, Journal of Business Ethics, 125 (2013) No. 4, pp. 563-580, doi:10.1007/s10551-013-1928-3

[26] Fassin, Y., Rossesn, A., \& Buelens, M.: Small-business owner-managers' perceptions of business ethics and CSR-related concepts, Journal of Business Ethics, 98 (2011) No. 3, pp. 425-453

[27] Fornell, C., \& Larcker, D. F.: Evaluating structural equation models with unobservable variables and measurement error, Journal of Marketing Research, 18 (1981) No. 1, pp. 39-50

[28] Glavas, A., \& Godwin, L. N.: Is the perception of 'goodness' good enough? exploring the relationship between perceived Corporate Social Responsibility and employee organizational identification, Journal of Business Ethics, 114 (2013) No. 1, pp. 15-27, doi:10.1007/s10551-012$1323-5$

[29] Grant, A. M.: The significance of task significance: Job performance effect, relational mechanisms, and boundary conditions, Journal of Applied Psychology, 93 (2008) No. 1, pp. 108-124

[30] Grant, A. M., Campbell, E. M., Chen, G., Cottone, K., Lapedis, D., \& Lee, K.: Impact and the art of motivation maintenance: the effects of contact with beneficiaries on persistence behavior, Organizational Behavior and Human Decision Processes, 103 (2007) No. 1, pp. 53-67

[31] Greening, D. W., \& Turban, D. B.: Corporate social performance as a competitive advantage in attracting a quality workforce, Business \& Society, 39 (2000) No. 3, pp. 254-280, doi:10.1177/000765030003900302 
[32] Hair, J., Black, W., Babin, B., Anderson, R., \& Tatham, R.: Multivariate data analysis (6 ${ }^{\text {th }}$ edition ed.), NJ: Prentice-Hall, 2006

[33] Hair, J. F. J., Babin, B., Money, A. H., \& Samouel, P.: Essentials of business research methods, New York:Wiley, 2003

[34] Hoivic, H. V. W., \& Mele, D.: Can a SME become a global corporate citizen? Evidence from a case study, Journal of Business Ethics, 88 (2009) No. 3, pp. 551-563, 10.1007/s10551-009-0123-z

[35] Husted, B. W., \& De Jesus Salazar, J.: Taking Friedman seriously: maximizing profits and social performance, Journal of Management Studies, 43 (2006) No. 1, pp. 75-91, doi:10.1111/j.1467-6486.2006.00583.x

[36] Iacobucci, D., Saldanha, N., \& Deng, X.: A meditation on mediation: evidence that structural equations models perform better than regressions, Journal of Consumer Psychology, 17 (2007) No. 2, pp. 139-153, doi:http://dx.doi.org/10.1016/S1057-7408(07)70020-7

[37] Jamali, D., Zanhour, M., \& Keshishian, T.: Peculiar strengths and relational attributes of SMEs in the context of CSR, Journal of Business Ethics, 87(2009) No. 3, pp. 355-377

[38] Jenkins, H.: Small business champions for Corporate Social Responsibility, Journal of Business Ethics, 67 (2006) No. 3, pp. 241-256, doi:10.1007/s10551-006-9182-6

[39] Jöreskog, K. G., \& Sörbom, D.: PRELIS 2: User's reference guide, Lincolnwood, IL: Scientific Software International, Inc, 1999

[40] Kamasak, R., James, S. R., \& Yavuz, M.: The interplay of corporate social responsibility and corporate political activity in emerging markets: The role of strategic flexibility in non-market strategies, Business Ethics-A European Review, 28 (2019) No. 3, pp. 305-320

[41] Kolodinsky, R. W., Madden, T. M., Zisk, D. S., \& Henkel, E. T.: Attitudes about corporate social responsibility: business student predictors, Journal of Business Ethics, 91 (2010) No. 2, pp. 167-181

[42] Lee, E. M., Park, S. Y., \& Lee, H. J.: Employee perception of CSR activities: Its antecedents and consequences, Journal of Business Research, 66 (2013) No. 10, pp. 1716-1724, doi:http://dx.doi.org/10.1016/ j.jbusres.2012.11.008

[43] Lu, J., Ren, L., He, Y., Lin, W., \& Streimikis J.: Linking Corporate Social Responsibility with reputation and brand of the firm, Amfiteatru Economic, 21 (2019) No. 51, pp. 442-460

[44] Lu, J., Ren, L., Qiao, J., Lin, W., \& He, Y.: Female executives and corporate social responsibility performance: a dual perspective of differences in institutional environment and heterogeneity of foreign 
experience, Transformations in Business \& Economics, 18 (2019) No. 2, pp. 174-196

[45] Luo, X., \& Bhattacharya, C. B.: Corporate Social Responsibility, customer satisfaction, and market value, Journal of Marketing, 70 (2006), No. 4, pp. $1-18$

[46] Maignan, I., \& Ferrell, O. C.: Measuring corporate citizenship in two countries: the case of the United States and France, Journal of Business Ethics, 23(2000) pp. 283-297

[47] Maignan, I., \& Ferrell, O. C.: Antecedents and benefits of corporate citizenship: An investigation of French businesses, Journal of Business Research, 51 (2001) No. 1, pp. 37-51

[48] Maignan, I., Ferrell, O. C., \& Hult, G. T. M.: Corporate citizenship: cultural antecedents and business benefits, Journal of the Academy of Marketing Science, 27, (1999) No. 4, pp. 455-469

[49] Margolis, J. D., \& Walsh, J. P.: Misery loves companies: rethinking social initiatives by business, Administrative Science Quarterly, 48 (2003) No. 2, pp. 268-305

[50] Matzler, K., \& Hinterhuber, H. H.: How to make product development projects more successful by integrating Kano's model of customer satisfaction into quality function deployment, Technovation, 18 (1998) No. 1, pp. $25-38$

[51] McWilliams, A., \& Siegel, D. S.: Creating and capturing value: strategic corporate social responsibility, resource-based theory and sustainable competitive advantage, Journal of Management, 37 (2010) No. 5, pp. 14801495

[52] Michelon, G., Boesso, G., \& Kumar, K.: Examining the link between strategic Corporate Social Responsibility and company performance: an analysis of the best corporate citizens, Corporate Social Responsibility and Environmental Management, 20 (2013) No. 2, pp. 81-94, doi:10.1002/csr.1278

[53] Mohr, L. A., Webb, D. J., \& Harris, K. E.: Do consumers expect companies to be socially responsible? The impact of corporate social responsibility on buying behavior, The Journal of Consumer Affairs, 35 (2011) No. 1, pp. $45-72$

[54] Murillo, D., \& Lozano, M.: SMEs and CSR: an approach to CSR in their own words, Journal of Business Ethics, 67 (2006) No. 3, pp. 227-240

[55] Nejati, M., \& Ghasemi, S.: Corporate social responsibility in Iran from the perspective of employees, Social Responsibility Journal, 8 (2012) No. 4, pp. 578-588, doi:10.1108/17471111211272552 
[56] Ogola, F. O., \& Mària, J.F.: Mechanisms for development in corporate citizenship: a multi-level review, International Journal of Corporate Social Responsibility, 5 (2020) p. 7, https://doi.org/10.1186/s40991-020-00051-5

[57] Pastrana, N. A., \& Sriramesh, K.: Corporate Social Responsibility: perceptions and practices among SMEs in Colombia, Public Relations Review, 40 (2014) No. 1, 14-24

[58] Peng, M. W.: Global business.Cincinnati: South-Western Cengage Learning, 2010

[59] Perez, A., de los Salmones, M. D. G., Liu, M. T.: Maximising business returns to corporate social responsibility communication: An empirical test, Business Ethics-A European Review, 28 (2019) No. 3, pp. 275-289

[60] Perrini, F.: SMEs and CSR theory: evidence and implications from an Italian perspective, Journal of Business Ethics, 67 (2006) No. 3, pp. 305316

[61] Perrini, F., Russo, A., Tencati, A., \& Vurro, C.: Deconstructing the relationship between corporate social and financial performance, Journal of Business Ethics, 102 (2011) No. 1, pp. 59-76

[62] Peterson, D. K.: The relationship between perceptions of corporate citizenship and organizational commitment, Business \& Society, 43(2004) No. 3, pp. 296-319, doi:10.1177/0007650304268065

[63] Pornchokchai, S.: Housing finance mechanism in Thailand: Nairobi, Kenya: UN-Habitat, 2008

[64] Porter, M. E., \& Kramer, M. R.: Creating shared value, Harvard Business Review 89 (2011) (January-February) pp. 62-77

[65] Porter, M. E., \& van der Linde, C.: Toward a new conception of the environmental competitiveness relationship, Journal of Economic Perspectives, 9 (1995) No. 4, pp. 97-118

[66] Psomas, E. L., \& Fotopoulos, C. V.: Total quality management practices and results in food companies, International Journal of Productivity and Performance Management, 59 (2010) No. 7, pp. 668-687

[67] Pucheta-Martinez, M. C., Bel-Oms, I., \& Olcina-Sempere, G.: Commitment of independent and institutional women directors to corporate social responsibility reporting, Business Ethics-A European Review, 28 (2019) No. 3, pp. 290-304

[68] Rao-Nicholson, R., Khan, Z., \& Marinova, S. T.: Balancing social and political strategies in emerging markets: evidence from India, Business Ethics-A European Review, 28 (2019) No. 1, pp. 56-70

[69] Raszkowski, A., Bartniczak, B.: Towards sustainable regional development: economy, society, environment, good governance based on 
the example of Polish regions, Transformations in Business \& Economics, 17 (2018) No. 2, pp. 225-245

[70] Rego, A., Leal, S., Cunha, M. P., Faria, J., \& Pinho, C.: How the perceptions of five dimensions of corporate citizenship and their interinconsistencies predict affective commitment, Journal of Business Ethics, 94 (2010) No. 1, pp. 107-127, doi:10.1007/s10551-009-0252-4

[71] Renouard, C., \& Ezvan, C.: Corporate social responsibility towards human development: acapabilities framework, Business Ethics-A European Review, 27 (2018) No. 2, pp. 144-155

[72] Riketta, M.: Organizational identification: A meta-analysis, Journal of Vocational Behavior, 66 (2005) No. 2, pp. 358-384, doi:http://dx.doi.org/ 10.1016/j.jvb.2004.05.005

[73] Rothenhoefer, L. M.: The impact of CSR on corporate reputation perceptions of the public-A configurational multi-time, multi-source perspective, Business Ethics-A European Review, 28 (2019) No. 2, pp. $141-155$

[74] Rodrigo, P., \& Arenas, D.: Do employees care about CSR programs? A typology of employees according to their attitudes, Journal of Business Ethics, 83 (2008) No. 2, pp. 265-283, doi:10.1007/s10551-007-9618-7

[75] Rowley, T., \& Berman, S.: A brand new brand of corporate social performance, Business \& Society, 39 (2000) No. 4, pp. 397-418, doi:10.1177/000765030003900404

[76] Russo, A., \& Perrini, F.: Investigating stakeholder theory and social capital: CSR in large firms and SMEs, Journal of Business Ethics, 91 (2010) No. 2, pp. 207-221

[77] Russo, F.: What is the CSR's focus in healthcare? Journal of Business Ethics, 124 (2016) pp. 323-334, doi:10.1007/s10551-014-2430-2

[78] Salehi, M., \& Azary, Z. H.: Stakeholders' perceptions of Corporate Social Responsibility: empirical evidences from Iran, International Business Research, 2 (2009) No. 1, pp. 63-72

[79] Samy, M., Odemilin, G., \& Bampton, R.: Corporate Social Responsibility: a strategy for sustainable business success. An analysis of 20 selected British companies, Corporate Governance, 10 (2010) No. 2, pp. 203-217

[80] Sangle, S.: Critical success factors for corporate social responsibility: a public sector perspective, Corporate Social Responsibility and Environmental Management, 17 (2009) No. 4, pp. 205-214

[81] Scherer, A. G., \& Palazzo, G.: Toward a political conception of corporate responsibility: business and society seen from a Habermasian Perspective, Academy of Management Review, 32 (2007) No. 4, pp. 1096-1120 
[82] Sen, S., \& Bhattacharya, C. B.: Does doing good always lead to doing better? consumer reactions to corporate social responsibility, Journal of Marketing Research, 38 (2001) No. 2, pp. 225-243

[83] Shen, C. H., \& Chang, Y.: Does Corporate Social Responsibility improve financial performance? Evidence from FTSE4GOOD UK Index, Academia Economic Papers, 36 (2008) No. 3, pp. 341-385

[84] Smith, D., \& Rhiney, E.: CSR commitments, perceptions of hypocrisy, and recovery, International Journal of Corporate Social Responsibility, 5(2020) No. 1, pp. 1-12, https://doi.org/10.1186/s40991-019-0046-7 